\title{
A CONSTRUÇÃO DE UMA GRANDE PÁTRIA
}

\author{
(Discurso proferido pelo PROF. HUM- \\ BERTO GRANDE, por ocasião do almôço de \\ confraternização das Turmas de Estagiários \\ da Escola Superior de Guerra de 1961, rea- \\ lizado em 15 de dezembro de 1961).
}

Meus Senhores.

\section{1 - INTRODUÇÃO}

Em 1952, quando visitava a Itália, em Roma, dentro do recinto do famoso Coliseu, onde, no passado, os jogos atingiram o auge com as lutas entre homens e feras, contaram-me comovente história. Um cristão, nos tempos de Nero, foi lançado à arena para ser comido por um leão. Mas o leão, embora faminto, nada lhe fêz, porque o discípulo de Cristo algo the segredou à orelha. Assustado com o que ouviu, o leão voltou rápido à sua jaula, com os olhos arregalados e lambendo os beiços. Aí o entusiasmo da multidão, que enchia o circo, chegou ao delírio, e, com clamor, pediu o perdão do corajoso prisioneiro. O Imperador não teve dúvida em deferir a justa petição das massas, e antes de fazê-lo, perguntou ao herói do dia o que dissera ao leão. Respondeu-lhe o cristão que assim se dirigira ao esfomeado rei dos animais: discurso.

- Leão. Não me devore, porque, depois da comida, vai haver

À vista disso, o leão preferiu passar fome a ouvir eloqüentes palavras.

Tornei-me, desde então, fervoroso adepto do leão, e aqui confesso a todos, muito à puridade, que também quero antes não comer a ouvir discurso. Por isso compreendí a razão pela qual, em solenidades como esta, a praxe fixou que a falação seja alegre e jocosa. Cada coisa deve ser dita na ocasião oportuna.

A propósito, o eminente escritor português Prof. Fidelino de Figueiredo narra-nos o seguinte episódio da vida agitada de Miguel de Unamuno: 
"Um dia, em Bilbao, sua linda terra, de ambiente exótico em Espanha, Unamuno foi solicitado pela Casa del Pueblo para ir falar a uma assembléia de operários ávidos de palavras de cólera contra o regime político e seus homens... Aceitou o escritor o convite e na noite aprazada lá compareceu, na sala de conferências, onde a multidão se comprimia, transida de ansiedade. Algum energúmeno local fêz um discurso de introdução à palavra guiadora do mestre, que iria assinalar às consciências a senda segura para deixar aquela ominosa encruzilhada. E chegou a vez de Unamuno subir ao estrado ante um silêncio espectante...

Com o seu uniforme e a sua vozinha, Unamuno subiu à tribuna de Bilbao, tomou os seus papeis e inclinou-se para a presidência para se explicar, só com estas palavras:

- Versos místicos. $E^{\prime}$ do que êles precisam.

E principiou com a sua voz, que era débil, mas se incutia em nós e nos causava um duradoura vibração interior, a ler versos místicos, uns seus, outros, muitos mais, de grandes poetas emanuélicos espanhóis. E aquêle público de gente exaltada, que esperava da sua voz acentos de cólera para verberar a intervenção da corôa na campanha de Marrocos e a inépcia dos generais, que the fôra pedir lenha nova para o incêndio, manteve-se silencioso e calmo, ouviu, absorveu todo aquêle filtro sedante, que the ministrou o escritor, e saiu, entre meditabundo e sorridente, a dispersar-se, cada qual rumo da sua casa, a refletir no que ouvira e nem sempre compreendera, mas que Ihe deixara na alma écos estranhos - écos da alta beleza..."

Neste ágape, seguirei a magistral lição do filósofo espanhol, reiterada em Cartagena, quando, numa festa, discorrendo sôbre a Espanha e os espanhóis, disse: "Sinto-me obrigado, mais que a distrairvos com jogos vãos, a celebrar convosco um ofício de culto patriótico". Assim, também eu, ao invés de vos contar outras anedotas, tratarei convosco de coisas sérias, neste ambiente alegre e festivo, como costumavam fazer, em tais oportunidades, os povos cultos e civilizados, desde a Grécia antiga. Aliás, procedo dêsse modo, depois de prévia consulta formulada às Turmas, que querem, sobretudo, orientar-se sôbre os destinos da nação bras:leira, objetivando a construção de uma grande pátria.

\section{2 - O SENTIDO DA ESCOLA SUPERIOR DE GUERRA}

Durante um ano, prezados colegas, convivemos quase diàriamente nesta Escola, elaborando trabalhos de grupo, trabalhos de turma e trabalhos de planejamento, e fizemos diversas viagens e visitas de estudos em várias regiões do território nacional, de norte a sul, leste a oeste, tudo com o objetivo de aprendermos uma doutrina, uma política e uma técnica de segurança nacional.

O nosso curso, porém, chegou ao seu término. Dentro de mais 
alguns dias, retornaremos às nossa atividades profissionais, exercidas aqui ou em outros Estados da Federação. Aumentaremos as fileiras da ADESG, que cresce de ano para ano, dando à Nação homens preparados para resolverem os seus problemas. $E^{\prime}$ oportuno, pois, nesta solenidade, em face dos acontecimentos, meditarmos juntos mais uma vez sôbre o sentido desta Escola na civilização brasileira, para traçarmos as diretrizes que nos permitam, de futuro, uma ação conjunta no cenário nacional.

A Escola Superior de Guerra é, antes de tudo, um centro de estudos e pesquisas, onde civis e militares categorizados podem, em conjunto, aperfeiçoar os seus conhecimentos necessários ao exercício de funções de direção e ao planejamento da segurança nacional. Ora, no atual momento histórico em que o mundo está ameaçado por novas modalidades de guerra, e quando só os povos preparados subsistirão, nada é mais valioso para a nacionalidade que a união de civís com militares, em tôda e qualquer circunstância. Mas para que esta união exista e possa ampliar-se em todos os campos do Poder $\mathrm{Na}$ cional, é mister que haja disciplina econômica, disciplina política, disciplina jurídica e moral, disciplina militar e disciplina em todo o organismo social.

A disciplina foi, na opinião dos mais eminentes historiadores, a causa da grandeza de Roma antiga. "Não é a casualidade, escreveu Montesquieu, a que domina o mundo; demonstram-nos os romanos que viveram em prosperidade contínua, enquanto se governaram segundo certas leis, e sofreram constantes revezes, quando se guiaram por outras". Assim, as bôas leis daquêle tempo originaram-se da disciplina militar romana, como observou sàbiamente Max Weber; as más leis sobrevieram com a corrupção do heróico povo.

O Brasil, agora, necessita de muita disciplina. Disciplina para organizar o povo, porque a nação é uma coletividade disciplina, orgariizada e bem orientada; disciplina para desenvolver as nosas riquezas, aproveitar os nosos recursos naturais, incrementar a agricultura, exfōnsionar o comercio e estimular a indústria; disciplina para reabilitar o país, tirando-o da inércia, atraso e desorganização; disciplina, enfim para educar a raça e constituir uma pátria forte e poderosa, que atinja o máximo do seu desenvolvimento. A disciplina, que imelica continuidade de esfôrços, ação cordenada e regime no comportamento, faz a grandeza das nações.

Mas não há disciplina sem objetivo e finalidade. Por isso o nosso povo deve disciplinar-se, para realizar os seus objetivos permanentes, conjugando todos os seus esforços em tôrno de uma obra comum, de sugestivo programa de organização, capaz de despertar o seu entusiasmo e impulsionar a sua vontade criadora.

Compete às classes dirigentes elaborar aquêle incitativo programa de ação, para bem canalizar as forças vivas da nação. Eis aí 
a sua missão e grande responsabilidade na vida dos povos. Elas sempre devem dar o exemplo, isto é, o bom exemplo de espírito público, patriotismo, moralidade e critério de justiça, para assim meIhor servir o povo e beneficiar a coletividade. Nestas condições, teremos disciplina e organização da sociedade, como valores jurídicos. O direito, na minha opinião, é fenômeno da cultura que, através da norma, disciplina e orgânica a vida social, coercitivamente, pelo critério da Justiça.

\section{3 - O POVO E A UNIÃO NACIONAL}

No meu livro "O CULTO DA GRANDEZA", mostrei que não há antagonismo entre os conceitos de povo e elite. Esta simboliza a cabeça de um organismo social e expressa a alma de um povo como o seu elemento consciente e esclarecido. Não devemos por isso confundir o povo com o populacho, com a plebe, com a gentalha, nem a elite com a classe capitalista, com a aristocracia de sangue ou com os privilegiados da fortuna. Não. O povo é a população de um país, compreende todos os indivíduos da sociedade. Logo, a elite constitui uma parte dêsse mesmo povo.

Mas uma nação não pode ser só elite nem só povo, assim co. mo impossível à cabeça existir sem o corpo, ou ao corpo viver sem a cabeça. Sociològicamente, a estrutura social implica a existência dos dois elementos, em paz e harmonia, sem a predominância da aristocracia ou da massofobia. Estudemos, pois, as relações entre êsses dois fatores.

A democracia confere ênfase ao povo, porque quer o seu bem. estar, educação e cultura. Aliás, no conceito clássico, democracia é - govêrno do povo pelo povo e para o povo; é o regime da tolerância, da solidariedade e do respeito; é o regime da ordem, da paz e da harmonia; é o regime da normalidade e da legalidade. Não se confunde absolutamente com os regimes de fôrça e de arbitrarieda. de e de violência, pois é o regime do direito e da justiça.

Nestes têrmos, a história registra que há uma democracia asdendente e outra descendente, de acôrdo com o triunfo ou decadência da instituição. A democracia é ascendente, quando eleva o nível econômico, moral e social das massas. A democracia é descendente; quando rebaixa aquêle nível.

De acôrdo com êsses conceitos, cumpre precisar a missão das elites e a missão das massas.

A missão das elites é a de servir a coletividade dentro de um espírito de abnegação, desinterêsse e sacrifício. A missão das massas é obedecer as classes dirigentes, quando estas são autênticas e estão ao serviço do povo, que deve prestigiar os seus valôres, para dêles se beneficiar. 
A nação, o Estado, a cultura e a civilização representam sem. pre o resultado da solidariedade dos grupos sociais e da sociabilidade, da convivência e da compreensão, do entendimento e da aproximação dos elementos de um círculo social determinado.

No processo criador histórico, a Nação está em primeiro lugar, e representa o conjunto de fatôres sentimentais e afetivos que agregam uma coletividade num todo disciplinado, que sabe o que quer. Origina-se da fraternidade dos homens e do amor à pátria, com o respeito às tradições e desejo de realizações futuras. A observação dêsses fatos levou Renan à célebre afirmativa de que a existência de uma nação é um plebiscito quotidiano: "Ter glórias comuns no passado, uma vontade comum no presente; haver feito juntos grandes cousas, querer fazer outras mais; eis aqui as condições essen. ciais para ser um povo... No passado uma herança de glórias e remorsos; no porvir, um mesmo programa para realizar..." Assim a vida de uma nação é espiritual. Não se explica a sua estrutura íntima pelo sangue, língua e passado comuns; o eminente filósofo Ortega $Y$ Gasset ensinou que "sangue, língua e passado comuns são princípios estáticos, fatais, rígidos, inertes: são prisões". A nação é uma comunidade espiritual, animada dos mesmos sentimentos, idéias e vontades.

Não se forja uma nação sem muita vitalidade e espiritualidade. Nascem as emprêsas agrícolas, comerciais ou industriais, os grandes exércitos, as poderosas armadas e as invencíveis aviações, enfim, todos os magnos empreendimentos, do entusiasmo, do fervor patriótico, do amor ardente e vivaz por algo superior ao indivíduo.

Uma grande nação nasce do espírito de um povo, que sabe querer e deseịar com vigor. Por isso mesmo a construção de uma grande nação é uma verdadeira obra de arte, que consiste em obter, pelo mais variados recursos, a união nacional, união forjadora das grandes pátrias.

A união nacional, para ser mantida e desenvolvida, exige grandes estadistas, grandes juristas, grandes economistas, grandes generais, grandes almirantes e grandes brigadeiros, que encarnem, nos seus propósitos, a vontade do povo, que expressem as aspirações do país e que realizem os objetivos permanentes da nacionalidade.

O Brasil necessita, agora, mais do que nunca, da união nacional. Da união das fôrças armadas entre si, isto é, das fôrças de terra, mar e ar; da união das fôrças armadas com as fôrças civis, com as fôrças industriais e culturais. Essa união sòmente pode resultar da compreensão mútua, do conhecimento das respectivas atividades e numa convivência cordial, como se aprende a fazer na Escola Superior de Guerra, constituída anualmente de um corpo de estagiários civis e militares selecionados, os quais aqui vêm para serem treinados, em trabaIhos de conjunto, para a formulação e execução da política de segu- 
rança nacional. Temos aí, reunidos por tarefas comuns, não só as mais altas patentes das fôrças armadas, como médicos, advogados e en. genheiros, representantes das atividades agrárias, comerciais e industriais, técnicos de administração, juristas e altos funcionários públicos, diplomatas, professôres e pesquisadores, todos êles integrantes das classes dirigentes da nacionalidade.

Uma sociedade progride, quando toma consciência da solidariedade dos seus membros, quando os grupos e as classes colaboram, cooperam e agem em comum. $O$ industrial precisa do govêrno. $O$ govêrno, do militar.Êste, do civil. O médico não pode prescindir do jurista. Este, do dentista e assim por diante em tôda esfera da socia. bilidade, que vive de constantes relações, conhecimentos, polarizações e novos contatos. A vida é movimento, atividade e perpétuo dinamis. mo. Assim a vitalidade das instituições exige circulação e a quebra do pernicioso sistema do hermetismo dos departamentos estanques.

A união sempre fêz a grandeza dos povos. A união dos civis com os militares, dos patrões com os operários, dos funcionários com os industriais; enfim, do homem de ciência com o homem de ação. As verdadeiras bases de uma nação estão na união de todos dentro de um ideal comum.

Tendo em vista êsses princípios, a Turma dos Estagiários de 1961, constituída das Turmas do Curso Superior de Guerra e do Curso de Estado-Maior e Comando das Fôrças Armadas, escolheu para seu patrono o nome de Caxias, símbolo autêntico da nossa pátria forte e poderosa, porque foi o integrador da nossa nacionalidade.

CAXIAS é a expressão máxima do soldado brasileiro, que consubstância as virtudes da nossa valorosa gente. Por isso o seu vulto austero e heróico, eminente em todos os aspectos, cresce dia a dia na admiração do nosso povo, que está compreendendo a grandeza daquele imortal patrício.

Eis aí o alto sentido da nossa homenagem à memória do grande brasileiro, que foi um dos maiores construtores da nacionalidade, e cuịo exemplo patriótico, sempre atual, deve orientar os destinos do Brasil.

\section{4 - UMA ESCOLA DE PATRIOTISMO E AMIZADE}

Observou Ortega Y Gasset que uma nação não está nunca feita: "A nação está sempre ou fazendo-se, ou desfazendo-se. Tertium non datur. Ou está ganhando adesões, ou as está perdendo, segundo o seu Estado represente ou não à data uma emprêsa vivaz". A nação é, pois, uma realidade dinâmica, que pode crescer e desenvolver-se em vários sentidos, de acôrdo com as circunstâncias.

O Brasil, por exemplo, no momento necessita de verdadeiros mestres e líderes, para vencer a anarquia e confusão reinantes. Tudo 
devemos fazer para não justificar a afirmativa de que em $\circ$ nosso país tudo é grande, menos o homem.

Daí um imperativo. O brasileiro precisa compreender o imenso Brasil, para ser grande: grande no pensamento, grande no coração e grande na vontade. "Os grandes pensamentos, dizia Mazzini, criam os grandes povos".

Quando o nosso povo perceber o seu glorioso destino tornar-seá um povo forte e poderoso. "Tudo o que é grande educa, ensinava Goethe, desde que nos cientifiquemos da sua grandeza". Ora, o Brasil é grande, muito grande. Para estar à sua altura, cumpre pensar com grandeza.

O nosso país, agora, entrou na política mundial e exige, para desempenhar o seu papel na História, estadistas de larga visão, com o objetivo de identificar o brasileiro com a sua gente e o Estado com os interêsses nacionais. Por isso precisamos organizar o Brasil num povo de trabalhadores, educá-lo e dar sentido aos esfôrços de todos, porque, os povos laboriosos, aquêles que agem sob a inspiração de poderoso ideal, são, indiscutívelmente, os povos mais virtuosos e felizes, aquêles que constroem a prosperidade das nações e a grandeza da pátria.

O elemento decisivo da vitória é o trabalho, mas um trabalho disciplinado e organizado, intensivo e rendoso, exercido em todos os setores da atividade humana, quer no exército, marinha ou aviação, quer na política ou administração, quer nas fábricas ou usinas. Tudo isto mostra o papel do trabalho conjugado de todos e de cada um diante de um objetivo bem definido. O trabalho é a expressão do homem forte, do homem viril, que enfrenta as dificuldades, resolve os problemas, enfrenta todos os obstáculos, e se torna dominador da natureza, criando civilizações, formando as culturas, enfim, realizando tudo o que é de grande e nobre na vida, porque o trabalho é, efetivamente, o elemento construtor da grandeza humana.

Levaram-nos a tais conclusões os programas e métodos da Escola Superior de Guerra. Esta Escola é, na verdade, uma ESCOLA DE PATRIOTISMO, porque nela o Brasil é objeto permanente de todos os seus estudos. E é uma ESCOLA DE AMIZADE, porque estreita as relações afetivas entre civis e militares no amor de ambos para com a nossa gente, visando a estabelecer a convivência criadora de tôdas as fôrças nacionais num sentimento de brasilidade. "Que cada qual, homem ou povo, seja êle e não outro" - aconselhava Unamuno.

Com essa diretriz, dinamizemos a Naçã, para que o Brasil cres. ça, progrida e realize plenamente $\circ$ seu destino, e com o entusiasmo e colaboração do povo, construamos uma grande pátria, com amor, fé e ideal.

A brasilidade é a alma e o espírito do nosso país, em cujos ma- 
nanciais o Brasil tem que buscar a sua autenticidade e universidade, para um dia poder abrasileirar a América e poder abrasileirar o Mundo.

A grande questão é "chegar a ser o que se é" - doutrinava o velho Píndaro. Não imitemos ninguém. Sejamos fiéis à nossa própria natureza.

O Brasil é o nosso problema, mas a sua correta solução está na Cultura Brasileira.

Caros colegas e amigos!

Lancemos a nossa Escola Superior de Guerra neste Brasil infinito, como uma Escola aberta, dinâmica e fecunda, para mobilizar as nossas massas trabalhadoras em soberba arrancada de progresso e civilização.

Planejemos a nossa grande nação para a liberdade e a democracia, e nunca jamais para a escravidão e o totalitarismo. 